\title{
An Improved and Practical Method for Synthesizing of $\alpha$-Sanshools and Spilanthol
}

\author{
Akira Nakamura, Kazuki Mimaki, Ken-ichi Tanigami and Tomohiro Maegawa* \\ School of Pharmaceutical Sciences, Kindai University, Osaka, Japan
}

An efficient and practical route for the synthesis of $\alpha$-sanshools and spilanthol is described herein. Several modifications of an existing method enabled the preparation of the $(2 E, 6 Z, 8 E, 10 E)$-tetraene precursor of hydroxy- $\alpha$-sanshool in good yield. A highly selective Wittig reaction employing newly synthesized phosphonium salt with low deliquescence and long-term stability yielded the desired $Z$-form tetraene. This improved methodology was shown to be applicable to the efficient synthesis of $\alpha$-sanshool and spilanthol.

Keywords: sanshool, stereoselective synthesis, Wittig reaction, polyene, natural products

\section{OPEN ACCESS}

Edited by:

Satoru Tamura,

Iwate Medical University, Japan

Reviewed by:

Yosuke Uchiyama,

Kitasato University, Japan

Florenci Vicent González,

University of Jaume I, Spain

*Correspondence:

Tomohiro Maegawa

maegawa@phar.kindai.ac.jp

Specialty section: This article was submitted to

Organic Chemistry,

a section of the journal

Frontiers in Chemistry

Received: 21 January 2020

Accepted: 28 February 2020

Published: 17 March 2020

Citation:

Nakamura A, Mimaki K, Tanigami K and Maegawa T (2020) An Improved

and Practical Method for Synthesizing

of $\alpha$-Sanshools and Spilanthol.

Front. Chem. 8:187.

doi: 10.3389/fchem.2020.00187

\section{INTRODUCTION}

Sanshools are a family of polyunsaturated fatty acid amides, differing in the length and double bond geometry of the polyunsaturated (Figure 1), found in various Zanthoxylum species (Jang et al., 2008; Devkota et al., 2012; Greger, 2016). The various biological activities of hydroxy- $\alpha-$ sanshool 1 have attracted a great deal of interest in the scientific community (Koo et al., 2007; Bautista et al., 2008; Yang, 2008; Munekage et al., 2013; Tang et al., 2014; Kubota et al., 2015). However, the inherent instability of their conjugated $(6 Z, 8 E, 10 E)$-triene structures, which are prone to isomerization, oxidation, polymerization, and/or photo-degradation, make sanshools difficult to isolate from natural products (Yang, 2008).

The synthesis of $\mathbf{1}$ has been reported previously by two independent research groups. Igarashi and co-workers developed two stereoselective approaches to hydroxyl- $\alpha$-sanshool synthesis, both employing several metal reagents and requiring precise operations (Aoki et al., 2012; Igarashi et al., 2012). Toy and co-workers constructed a $(6 Z, 8 E, 10 E)$-conjugated triene precursor moiety with moderate selectivity $(6 Z: 6 E=2: 1)$ using the Wittig reaction; a pure stereoisomer was isolated by recrystallization ( $\mathrm{Wu}$ et al., 2012). The purpose of the current study was to produce high-purity hydroxy- $\alpha$-sanshool $\mathbf{1}$. Among the three existing synthesis methods, Toy's is the simplest due to the use of more conventional reagents and procedures. Our synthesis of $\mathbf{1}$ via Toy's method, however, proved difficult when following the literature, and resulted in reduced yields due to the instability or deliquescence of intermediate species. Therefore, we set out to enhance the general practicality and robustness of Toy's method of sanshool synthesis.

\section{RESULTS AND DISCUSSION}

Our synthesis of hydroxy- $\alpha$-sanshool began with the oxidation of 4-bromobutan-1-ol with PCC, which was poorly reproducible on the gram scale. A more effective strategy was catalytic oxidation using commercially available AZADOL as the catalyst and sodium hypochlorite pentahydrate $\left(\mathrm{NaClO} \cdot 5 \mathrm{H}_{2} \mathrm{O}\right)$ as a co-oxidant (Scheme 1) (Okada et al., 2014). The desired 4-bromobutanal 2 was 


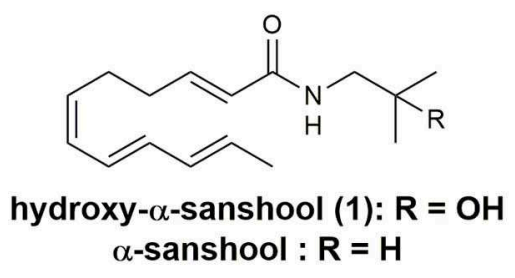<smiles>[R]C(C)(C)CNC(=O)/C=C/C=C/C/C=C\C=C/C</smiles>

hydroxy- $\gamma$-sanshool : $\mathrm{R}=\mathrm{OH}$ $\gamma$-sanshool : $\mathbf{R}=\mathbf{H}$<smiles>[R]C(C)(C)CNC(=O)/C=C/CC/C=C/C=C/C=C\C</smiles>

hydroxy- $\beta$-sanshool : $\mathbf{R}=\mathrm{OH}$ $\beta$-sanshool : $\mathbf{R}=\mathbf{H}$<smiles>C/C=C\C=C/C=C\CC/C=C/C(=O)NCC(C)(C)O</smiles>

hydroxy- $\varepsilon$-sanshool

FIGURE 1 | Sanshool compounds.
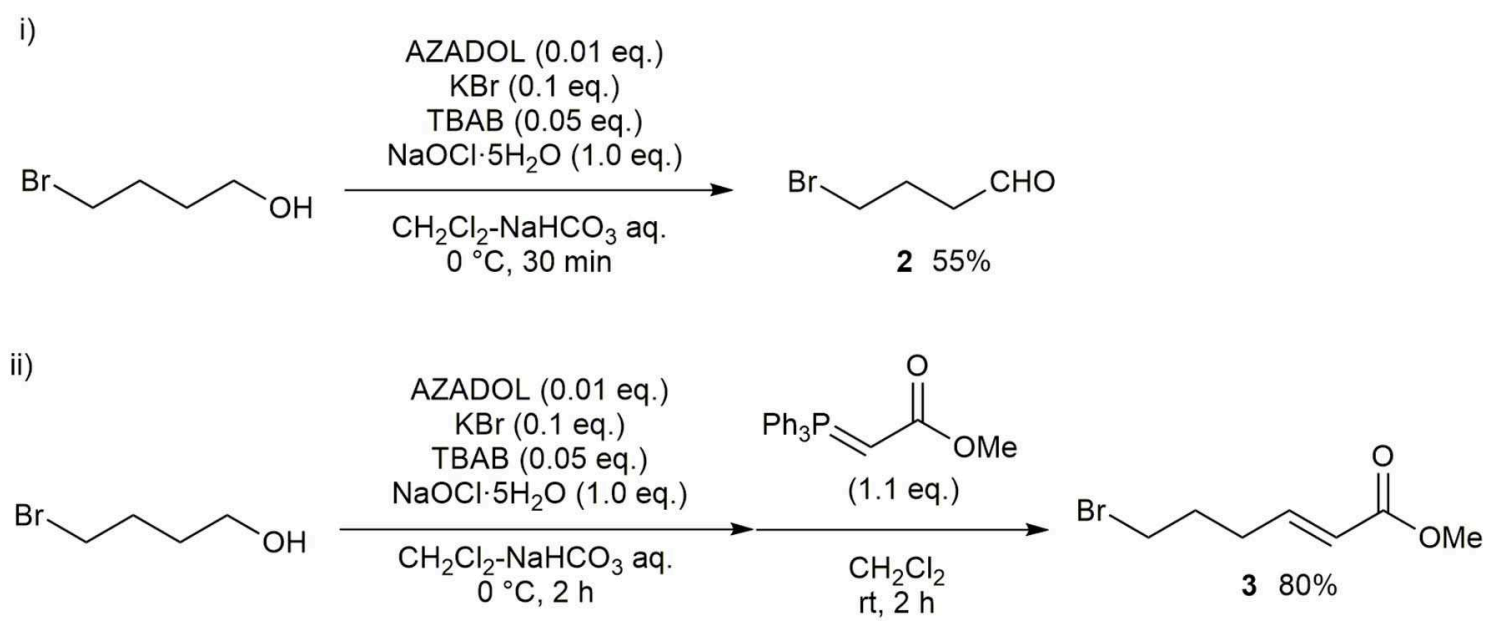

SCHEME 1 | Synthesis of ester $\mathbf{3}$.

produced in 55\% yield together with small amounts of 4-bromobutanoic acid. These results were reproducible even on the gram scale (Scheme 1, i). Other nitroxyl radical catalysts did not improve the yield of $\mathbf{2}$. Note that partial decomposition of $\mathbf{2}$ during purification resulting in moderate overall yields. Then, the Horner-Wadsworth-Emmons (HWE) reaction was conducted, resulting in ester 3 in $80 \%$ yield (Scheme 1, ii).

In an effort to improve the selectivity of the Wittig reaction $(6 Z: 6 E=2: 1)$, we converted ester 3 to its corresponding phosphonium salt $\mathbf{4 a}$ with $\mathrm{PPh}_{3}$ according to Toy's synthesis method. However, this reaction suffered from low reproducibility due to the high deliquescence of $\mathbf{4 a}$. We therefore evaluated several methods to create a phosphonium salt $\mathbf{4}$ with lower hygroscopicity (Scheme 2). First, ester 3 was hydrolyzed to carboxylic acid $\mathbf{5}$ and the phosphonium salt $\mathbf{4 b}$ was obtained in good yield by the reaction with $\mathrm{PPh}_{3}$. Unfortunately, $\mathbf{4 b}$ exhibited deliquescence similar to that of $\mathbf{4 a}$. To determine the influence of the phosphonium salt counter anion on deliquescence, we prepared the iodonium salt $4 \mathbf{c}$ using the corresponding alkyl iodide 6. However, this also resulted in a compound with high deliquescence. We found that the combination of counter anion and functional group is important in determining the deliquescence of phosphonium salts, and obtained the nondeliquescent iodine salt $\mathbf{4 d}$ from the iodo ester 7 .

We next examined the stereoselective synthesis of tetraene 8 with 4 d. The results of the Wittig reaction of $(2 E, 4 E)$ 2,4-hexadienal 9 with phosphonium salt $4 \mathbf{d}$ under various reaction conditions are summarized in Table $\mathbf{1}$. When $t$-BuOK or $\mathrm{NaH}$ was used as a base, tetraene $\mathbf{8}$ was obtained in moderate yields and $6 Z / 6 E$ stereoselectivity (entries 1 and 2). The use of potassium bis(trimethylsilyl)amide (KHMDS) as a base afforded the best results. The use of KHMDS at $-40^{\circ} \mathrm{C}$ improved the stereoselectivity of the product to $12: 1$, but with a slight decrease in yield (Entry 3 ). Conducting the reaction at $-78^{\circ} \mathrm{C}$ failed to yield the desired product 8 (Entry 4). However, gradually increasing the temperature to $-40^{\circ} \mathrm{C}$ from 
<smiles>COC(=O)/C=C/CCC[Pb](=O)OCC(=O)OC</smiles><smiles>O=C(O)/C=C/CCC[PH3+]Br</smiles><smiles>O=C(O)/C=C/CCCI</smiles><smiles>O=C(O)/C=C/CCC[PH3+]</smiles><smiles>COC(=O)/C=C/CCCI</smiles>

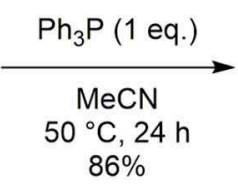<smiles>COC(=O)/C=C/CCC[PH+](F)F</smiles>

SCHEME 2 | Investigation of phosphonium salt.

TABLE 1 | Optimization of Wittig reaction.

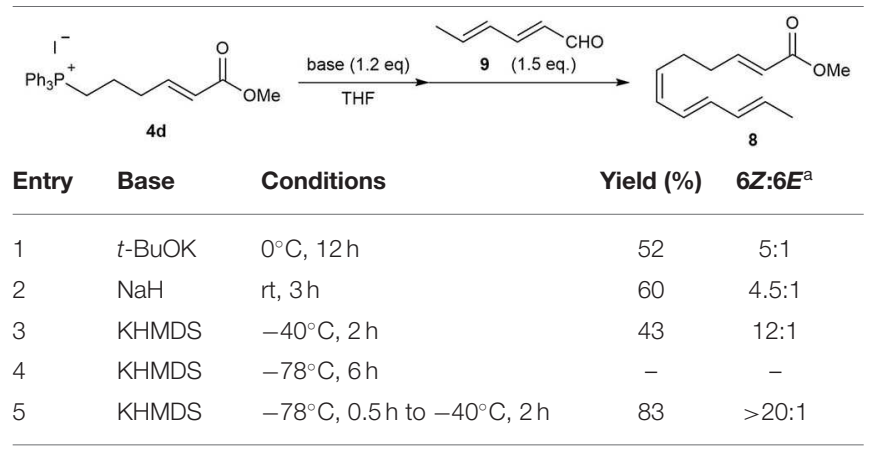

${ }^{a}$ The ratio of stereoisomers was determined by ${ }^{1} \mathrm{H}$ NMR analysis.

$-78^{\circ} \mathrm{C}$, after the addition of $\mathbf{9}$ to the ylide generated from $4 \mathbf{d}$, resulted in tetraene 8 in high yield and high $6 Z / 6 E$ selectivity (Entry 5) (Uchiyama et al., 2017). However, other tetraene isomers, derived from small amounts of stereoisomers contained in commercially available (2E,4E)-2,4-hexadienal 9, were still observed. We finally succeeded in obtaining $(2 E, 6 Z, 8 E, 10 E)$ tetraene 8 as a single isomer in $83 \%$ yield by using pure $(2 E, 4 E)$ 2,4-hexadienal 9 prepared from $(2 E, 4 E)$-2,4-hexadien-1-ol with manganese oxide.

Then, following Toy's method, ester 8 was converted to carboxylic acid $\mathbf{1 0}$ in $83 \%$ yield (Scheme 3 ). Amide formation, via the coupling of $\mathbf{1 0}$ and the appropriate amine using HBTU and $\mathrm{Et}_{3} \mathrm{~N}$, afforded hydroxy- $\alpha$-sanshool $\mathbf{1}$ and $\alpha$ sanshool 11 in $88 \%$ and $92 \%$ yields, respectively (please see Supplementary Material).

The developed method was applied to the synthesis of the biologically active compound spilanthol (Sharma et al., 2011; Barbosa et al., 2016), also known as affinin, which contains a $(2 E, 6 Z, 8 E)$-decatrienamide moiety (Scheme 4). Several synthetic methods for spilanthol have been reported (Crombie et al., 1963; Ikeda et al., 1984, Ikeda et al., 1987). A recent short step synthesis by Pastre provided high stereoselectivity, but suffered from a relatively low overall yield of 18\% (Alonso et al., 2018). Our synthesis, starting from the Wittig reaction of the ylide generated from $4 \mathbf{d}$ and crotonaldehyde to afford ester 12 , resulted in a $95 \%$ yield of the $(2 E, 6 Z, 8 E)$-single stereoisomer. Saponification of $\mathbf{1 2}$ gave carboxylic acid $\mathbf{1 3}$ in $91 \%$ yield. Spilanthol was then synthesized in $84 \%$ yield using the coupling reaction employed in the $\alpha$-sanshool synthesis. Thus, the efficient and stereoselective synthesis of spilanthol was achieved from 4-bromobutanol in six steps with an overall yield of $47 \%$.

\section{CONCLUSION}

We developed a practical and reproducible method for the synthesis of hydroxy- $\alpha$-sanshool and $\alpha$-sanshool. Notably, modifications of the Wittig reaction using a newly synthesized, 


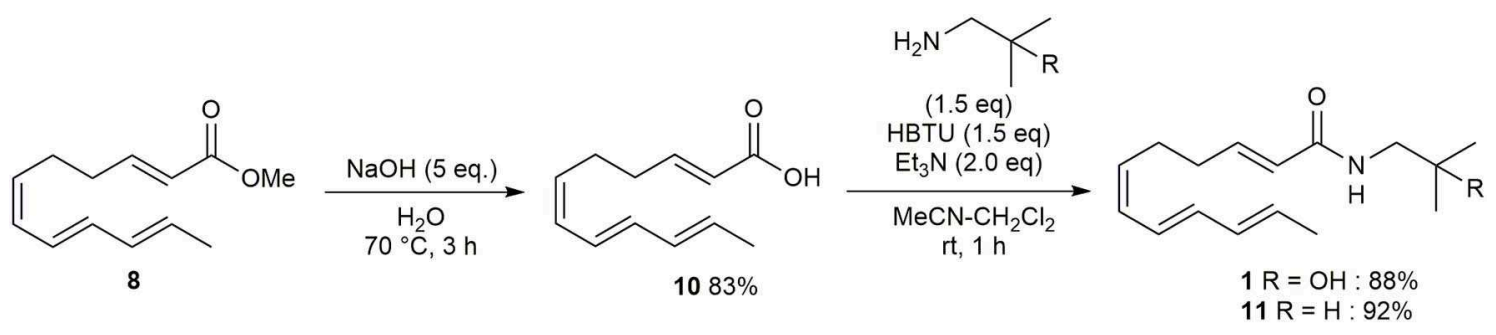

SCHEME $\mathbf{3}$ | Synthesis of hydroxy- $\alpha$-sanshool $\mathbf{1}$ and $\alpha$-sanshool $\mathbf{1 1}$.

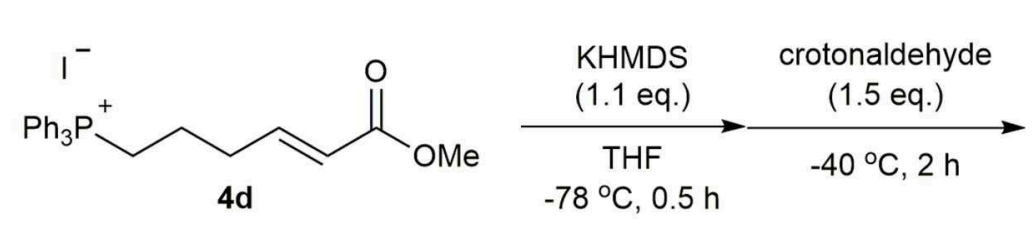<smiles>COC(=O)/C=C/CC/C=C\C=C/c1ccccc1</smiles><smiles>C/C=C\C=C/CC/C=C/C(=O)O</smiles>

$1391 \%$<smiles>CC(C)CN</smiles>

(1.5 eq.)<smiles>C/C=C\C=C/CC/C=C/C(=O)NCC(C)C</smiles>

$\mathrm{rt}, 1 \mathrm{~h}$

Spilanthol

$84 \%$

SCHEME 4 | Synthesis of spilanthol.

non-deliquescent phosphonium salt under low-temperature conditions succeeded in forming single stereoisomers of $(2 E, 6 Z, 8 E, 10 E)$-tetraene and $(2 E, 6 Z, 8 E)$-triene moieties in good yields. This method was shown to be applicable to the synthesis of spilanthol in six steps, resulting in an overall yield of $47 \%$. Further studies on the synthesis of other sanshool derivatives are ongoing.

\section{DATA AVAILABILITY STATEMENT}

All datasets generated for this study are included in the article/Supplementary Material.

\section{AUTHOR CONTRIBUTIONS}

$\mathrm{AN}, \mathrm{KM}$, and $\mathrm{KT}$ performed the experiments. $\mathrm{AN}$ and $\mathrm{TM}$ wrote the manuscript. All authors designed the experiments and were involved in the data analysis. All authors designed

\section{REFERENCES}

Alonso, I. G., Yamane, L. T., de Freitas-Blanco, V. S., Novaes, L. F. T., FranzMontan, M., de Paula, E., et al. (2018). A new approach for the total synthesis of spilanthol and analogue with improved anesthetic activity. Tetrahedron 74, 5192-5199. doi: 10.1016/j.tet.2018.06.034 the experiments, were involved in the data analysis, and have expressed approval of the final version of the manuscript.

\section{FUNDING}

This work was financially supported by JSPS KAKENHI Grant Nos. 19K16329 and 18K05132.

\section{ACKNOWLEDGMENTS}

We thank the Kindai University Joint Research Center for use of their facilities.

\section{SUPPLEMENTARY MATERIAL}

The Supplementary Material for this article can be found online at: https://www.frontiersin.org/articles/10.3389/fchem. 2020.00187/full\#supplementary-material

Aoki, K., Igarashi, Y., Nishimura, H., Morishita, I., and Usui, K. (2012). Application of iron carbonyl complexation to the selective total synthesis of sanshools. Tetrahedron Lett. 53, 6000-6003. doi: 10.1016/j.tetlet.2012.08.135

Barbosa, A. F., de Carvalho, M. G., Smith, R. E., and Sabaa-Srur, A. U. O. (2016). Spilanthol: occurrence, extraction, chemistry and biological activities. Rev. Bras. Farmacogn. 26, 128-133. doi: 10.1016/j.bjp.2015.07.024 
Bautista, D. M., Sigal, Y. M., Milstein, A. D., Garrison, J. L., Zorn, J. A., Tsuruda, P. R., et al. (2008). Pungent agents from Szechuan peppers excite sensory neurons by inhibiting two-pore potassium channels. Nat. Neurosci. 11, 772-779. doi: 10.1038/nn.2143

Crombie, L., Krasinski, A. H. A., and Manzoor-i-Khuda, M. (1963). Amides of vegetable origin. Part X. The stereohemistry and synthesis of affinin. J. Chem. Soc. 4970-4976. doi: 10.1039/JR9630004970

Devkota, K. P., Wilson, J., Henrich, C. J., McMahon, J. B., Reilly, K. M., and Beutler, J. A. (2012). Isobutylhydroxyamides from the pericarp of Nepalese Zanthoxylum armatum inhibit NF1-defective tumor cell line growth. J. Nat. Prod. 76, 59-63. doi: 10.1039/C7NP00044H

Greger, H. (2016). Alkamides: a critical reconsideration of a multifunctional class of unsaturated fatty acid amides. Phytochem. Rev. 15, 729-770. doi: 10.1007/s11101-015-9418-0

Igarashi, Y., Aoki, K., Nishimura, H., Morishita, I., and Usui, K. (2012). Total synthesis of hydroxy- $\alpha$ - and hydroxy- $\beta$-sanshool using Suzuki-Miyaura coupling. Chem. Pharm. Bull. 60, 1088-1091. doi: 10.1248/cpb.c12-00382

Ikeda, Y., Ukai, J., Ikeda, N., and Yamamoto, H. (1984). Facile routes to natural acyclic polyenes syntheses of spilanthol and trail pheromone for termite. Tetrahedron Lett. 25, 5177-5180. doi: 10.1016/S0040-4039(01)81556-2

Ikeda, Y., Ukai, J., Ikeda, N., and Yamamoto, H. (1987). Stereoselective synthesis of 1,4-disubstituted 1,3-diene from aldehyde using organotitanium reagent. Tetrahedron 43, 731-741. doi: 10.1016/S0040-4020(01)90007-9

Jang, K. H., Chang, Y. H., Kim, D.-D., Oh, K.-B., Oh, U., and Shin, J. (2008). New polyunsaturated fatty acid amides isolated from the seeds of Zanthoxylum piperitum. Arch. Pharm. Res. 31, 569-572. doi: 10.1007/s12272-001-1194-5

Koo, J. Y., Jang, Y., Cho, H., Lee, C. H., Jang, K. H., Chang, Y. H., et al. (2007). Hydroxy-alpha-sanshool activates TRPV1 and TRPA1 in sensory neurons. Eur. J. Neurosci. 26, 1139-1147. doi: 10.1111/j.1460-9568.2007.05743.x

Kubota, K., Ohtake, N., Ohbuchi, K., Mase, A., Imamura, S., Sudo, Y., et al. (2015). Hydroxy- $\alpha$-sanshool induces colonic motor activity in rat proximal colon: a possible involvement of KCNK9. Am. J. Physiol. Gastrointest. Liver Physiol. 308, G579-G590. doi: 10.1152/ajpgi.00114.2014

Munekage, M., Ichikawa, K., Kitagawa, H., Ishihara, K., Uehara, H., Watanabe, J., et al. (2013). Population pharmacokinetic analysis of daikenchuto, a traditional
Japanese medicine (Kampo) in Japanese and US health volunteers. Drug Metab. Dispos. 41, 1256-1263. doi: 10.1124/dmd.112.050112

Okada, T., Asawa, T., Sugiyama, Y., Kirihara, M., Iwai, T., and Kimura, Y. (2014). Sodium hypochlorite pentahydrate $\left(\mathrm{NaOCl} \cdot 5 \mathrm{H}_{2} \mathrm{O}\right)$ crystals as an extraordinary oxidant for primary and secondary alcohols. Synlett 25, 596-598. doi: 10.1055/s-0033-1340483

Sharma, V., Boonen, J., Chauhan, N. S., Thakur, M., de Spiegeleer, B., and Dixit, V. K. (2011). Spilanthes acmella ethanolic flower extract: LC-MS alkylamide profiling and its effects on sexual behavior in male rats. Phytomedicine 18, 1161-1168. doi: 10.1016/j.phymed.2011.06.001

Tang, X., Zhou, X., Wu, J., Li, J., and Bai, L. (2014). A novel function of sanshools: the alleviation of injury from metolachlor in rice seedlings. Pestic. Biochem. Physiol. 110, 44-49. doi: 10.1016/j.pestbp.2014. 02.006

Uchiyama, Y., Ohtsuki, T., Murakami, R., Shibata, M., and Sugimoto, J. (2017). (E)Selective Wittig reactions between a nonstabilized phosphonium ylide bearing a phosphastibatriptycene skeleton and benzaldehydes. Eur. J. Org. Chem. 1, 159-174. doi: 10.1002/ejoc.201601098

Wu, B., Kun, L., and Toy, P. H. (2012). Synthesis of hydroxy- $\alpha$-sanshool. Synlett 23, 2564-2566. doi: 10.1055/s-0032-1317172

Yang, X. (2008). Aroma constituents and alkylamides of red and green Huajiao (Zanthoxylum bungeanum and Zanthoxylum schinifolium). J. Agric. Food Chem. 56, 1689-1696. doi: 10.1021/jf0728101

Conflict of Interest: The authors declare that the research was conducted in the absence of any commercial or financial relationships that could be construed as a potential conflict of interest.

Copyright (c) 2020 Nakamura, Mimaki, Tanigami and Maegawa. This is an openaccess article distributed under the terms of the Creative Commons Attribution License (CC BY). The use, distribution or reproduction in other forums is permitted, provided the original author(s) and the copyright owner(s) are credited and that the original publication in this journal is cited, in accordance with accepted academic practice. No use, distribution or reproduction is permitted which does not comply with these terms. 